Article History

Received: June 10, 2021

Revised: Sep. 28, 2021

Accepted: Dec. 5, 2021
ISSN:2565-4942 (Print) 2738-9693 (Online)

Nepalese Journal of Insurance and Social Security, Year 2021, Volume 4, Issue (1),

Page 51-64. https://nirma.com.np

DOI: https://doi.org/10.3126/njiss.v4i1.42354

\title{
Socio-economic status of the recipients of social security allowance: a case study of Kaski, Nepal
}

Deepesh Ranabhat $^{1 *}$, Sujita Adhikari², Pradeep Sapkota ${ }^{3}$, Mala Ranabhat ${ }^{4}$

*Corresponding author, email: deepeshrana2000@gmail.com

\begin{abstract}
The research aims to assess the impact of social security allowance on socio-economic status of the recipients and differences in socio-economic status of the recipients. Multistage sampling technique has been used for the selection of samples. The data has been collected through self-structured questionnaires from 170 respondents who have been receiving social security allowance provided by the Government of Nepal. Thus, descriptive as well as cross-sectional research design has been used for this study. The study found that social security benefits play very important role in improving socio-economic status of the beneficiaries by enhancing the economic well-being, health access, social status, self-respect and respect from others, and living standard of the recipients. The study also found that there is a significant difference in socio-economic well-being of recipients by area of residence, employment status, duration of getting allowance, and allowance as major source of income.
\end{abstract}

Keywords: Social security allowance, Old age allowance, Socio-economic status, Nepal.

\section{Introduction}

Social security benefit is the benefits provided by the government as a means of assisting low-income members of the society such as the unemployed, elderly, sick, retired, disabled, single-parent families, etc. The social security system assures the right of socially, economically, physically, and psychologically vulnerable people for a normal and dignified life. Social security allowances are non-contributory programs that target the poor and vulnerable section of the population and are designed to reduce poverty and inequality, enable better human capital investments, improve social risk management, and offer social protection to people (Khan, 2012). The social security benefit plays a vital role to motivate the people as it provides some protection against old age, disable, vulnerable groups of society, single women, etc. A social security system has been widely

\footnotetext{
${ }^{1}$ Faculty of Management Studies, Pokhara University, Pokhara Metropolitan-30, Kaski, Nepal Corresponding author, email: deepeshrana2000@gmail.com

${ }^{2}$ Faculty of Management Studies, Pokhara University, Pokhara Metropolitan-30, Kaski, Nepal

${ }^{3}$ Faculty of Management Studies, Pokhara University, Pokhara Metropolitan-30, Kaski, Nepal

${ }^{4}$ Pokhara University, Pokhara Metropolitan-30, Kaski, Nepal
} 
NJISS Volume $4 \quad$ Issue $1 \quad$ ISSN:2565-4942 (Print) 2738-9693 (Online)

established as a major policy instrument for enabling people to have basic living standards and arranging financial support against unforeseen risks.

Social security is being considered as a right of the citizen. It is a very important issue of every country. In Nepal, social welfare activities related to helpless women, children, senior citizens, and the disabled have been introduced in Eighth Plan (19921997) only. Before this, no due attention was given to the social security policy. At first, a universal flat pension of Rs. 100 to all the elderly people above 75 years was first announced in Nepal in 1994. Later on, the government has introduced allowances to single women, endangered races, people with full disability, and partial disability (National Planning Commission, 2012).

Social Security Allowance reinforces dignity, economic opportunities, respect, and social security for beneficiaries but there is little understanding of the impact and access of the social security allowance on people. Is it valued by them? Does it change the status of people? Does it have any social impact? Does the pension have an equal economic impact on all kinds of people? Who benefits the most from the pension? To answer these questions, an attempt has been made through this study. Hence, the present study aims at assessing the impact of social security allowances on the socio-economic status of people and factors affecting the socio-economic well-being of recipients in the Kaski District of Nepal.

\section{Review of Literature}

Various studies related to the socio-economic impact of allowance and the factors affecting socio-economic impact have been conducted. Unnikrishnan and Imai (2020) conducted a study to examine the impact of old age pensions on household welfare in India found that pension helps to increase the welfare of households as it helps to increase the consumption expenditure, food, and non-food expenditure of the recipients while reducing the labor supply. Old age allowance helps to get better care and attention from family members, more heath access, and more voice in the decision-making process. It also helps to be financially independent and enhances self-respect and respect from others (Hasan, 2012). A study conducted to examine the impact of the old age allowance (OAA) program on Bangladesh found that OAA helps aged persons to get better positions and respect in society and from family members. The programs have a positive impact on old-aged people but the economic impact is less than the social impact as the amount of allowance is small (Choudhary, 2013). Old age pension enhances the economic as well as mental well-being of old people by reducing sadness and produces the feeling of safety and welfare (Salinas-Rodríguez et al., 2014). Old age pension helps to reduce the working hours of the elderly on the farm and increase the time for grandchild care. It also increases financial independence, bargaining power, and welfare in old age (Li et al., 2018). Old-age pension increases access to formal health care services (Riumallo-Herl \& Aguila, 2019).

Dhungana et al. (2020) examined the satisfaction level and use of old age allowance in Nepal. The study found that the majority of the elderly are satisfied with the allowance as it helps to enhance the family relationship and allowance is mostly used for their personal expenditure, and then for health and medicine. Another study by Malakar and Chalise (2019) found 
NJISS Volume $4 \quad$ Issue 1 ISSN:2565-4942 (Print) 2738-9693 (Online)

that allowance is a major source of income for most of the elderly in Nepal but the amount is very less, it is not provided on time and there is a long queue in the office for getting allowance. A study conducted by Dhungana and Ranabhat (2018) found that education, marital status, and location are the major factors associated with the socio-economic status of the beneficiaries of old age allowance. Similarly, Mugomeri et al. (2017) shows that the old-age pension was the major source of income for the elderly people and the quality of life of elderly receiving old-age pension is affected by marital status, education level, sources of income, level of satisfaction with income, and type of house .

\section{Methodology}

This study employed a quantitative approach. The study is descriptive and cross-sectional in nature. The study mainly relies on primary data to meet the study objectives. Secondary data was also used to find out the distribution of social security allowance. The secondary sources of data include publications of the Central Bureau of Statistics (CBS) and the Ministry of Federal Affairs and Local Development (MOFALD). The study has been confined to the Kaski District of Nepal which is selected purposively as it is one of the major cities and capital city of Gandaki province of Nepal.

A multi-stage sampling technique was used to select the sample. At first, Rupa Rural Municipality and Pokhara Metropolitan city are selected purposively. Then two wards (6 \& 8) from Rupa Rural Municipality and two wards (26 \& 32) from Pokhara Metropolitan city were selected randomly. At the final stage, the researchers have selected 170 respondents ( 85 from each Municipality) as the sample size purposively at $7.5 \%$ margin of error and $95 \%$ confidence interval. Those people who are receiving social security allowance provided by the Government of Nepal and who can actively participate in the interview while collecting the data were taken as samples. A survey questionnaire was designed to collect data from the respondents. The survey questionnaire includes three section where section A includes demographic information, section $B$ includes basic information related to social security allowance and section $\mathrm{C}$ includes question related to socio-economic impact of allowance measured in Five-Point Likert scale. The reliability of Likert questions were measured by Cronbach's alpha which was found 0.889 and this value is good in SPSS reliability statistic (George \& Mallery, 2003). Both descriptive analysis (percentage analysis, mean), as well as inferential analysis (t-test and ANOVA), were used for data analysis using SPSS software.

\section{Results and Discussion}

\section{Demographic Profile of Respondents}

The demographic characteristics for the individual respondents have been characterized through gender, marital status, education, ethnic group, occupation, living arrangement, monthly income of a family, type of social security allowance, years of receiving an allowance, and area of respondents. The summary of the demographic characteristics of respondents has been presented in Table 1.

Ranabhat, Adhikari, Sapkota and Ranabhat 53 
NJISS Volume $4 \quad$ Issue 1 ISSN:2565-4942 (Print) 2738-9693 (Online)

Table 1

Demographic Profile of Respondents

\begin{tabular}{|c|c|c|c|c|c|}
\hline Demographic Variables & Freq. & Percent & Demographic Variables & Freq. & Percent \\
\hline \multicolumn{3}{|l|}{ Gender } & \multicolumn{3}{|l|}{ Living Arrangement } \\
\hline Male & 70 & 41.2 & Family & 104 & 61.2 \\
\hline Female & 100 & 58.8 & Spouse & 35 & 20.6 \\
\hline \multicolumn{3}{|l|}{ Marital status } & Alone & 27 & 15.9 \\
\hline Married & 92 & 54.1 & Daughter/Son-in-law & 4 & 2.4 \\
\hline Divorced/separated & 4 & 2.4 & \multicolumn{3}{|c|}{ Monthly Income of the family } \\
\hline Unmarried & 5 & 2.9 & 5000 and less & 52 & 30.6 \\
\hline Widow & 69 & 40.6 & 5001 to 10000 & 24 & 14.1 \\
\hline \multicolumn{3}{|l|}{ Education } & 10001 to 20000 & 20 & 11.8 \\
\hline Illiterate & 112 & 65.9 & 20001 to 30000 & 37 & 21.8 \\
\hline Basic education & 49 & 28.8 & Above 30000 & 37 & 21.8 \\
\hline Secondary education & 4 & 2.4 & \multicolumn{3}{|c|}{ Type of social security allowance } \\
\hline Above secondary level & 5 & 2.9 & Old age allowance & 86 & 50.6 \\
\hline \multicolumn{3}{|l|}{ Ethnic Group } & Widow Allowance & 41 & 24.1 \\
\hline Brahmin & 70 & 41.2 & Disabled Allowance & 10 & 5.9 \\
\hline Chhetri & 40 & 23.5 & Dalit Allowance & 33 & 19.4 \\
\hline Dalit & 34 & 20.0 & \multicolumn{3}{|c|}{ Years of Receiving an allowance } \\
\hline Janajati & 26 & 15.3 & less than 1 year & 12 & 7.1 \\
\hline \multicolumn{3}{|l|}{ Major Occupation } & 1 to 2 year & 22 & 12.9 \\
\hline Agriculture & 42 & 24.7 & 3 to 4 years & 33 & 19.4 \\
\hline Day Labor & 1 & 0.6 & 5 years and above & 103 & 60.6 \\
\hline Housewife & 22 & 12.9 & \multicolumn{3}{|l|}{ Area } \\
\hline Unemployed & 86 & 50.6 & Pokhara Metropolitan & 85 & 50.0 \\
\hline Others & 19 & 11.2 & Rupa Rural Municipality & 85 & 50.0 \\
\hline Total & 170 & 100.0 & Total & 170 & 100.0 \\
\hline
\end{tabular}

Source: Field survey, 2020.

The majority of the respondents are female (58.8\%). Most of the respondents $(54.1 \%)$ are married followed by the widow (40.6\%), unmarried (2.9\%), and divorced (2.4\%). The highest numbers of respondents are illiterate which comprise 65.9 percent. Similarly, 28.8 percent of respondents have basic education, 2.4 percent of respondents have secondary education, and 2.9 percent of respondents have secondary education. Most of the respondents are Brahmin that composes of 41.2 percent followed by Chhetri 23.5 percent, Dalit 20 percent, and Janajati 15.3 percent.

Table 1 reveals that nearly half of the respondents are working in a different occupation such as agriculture (24.7\%), as a housewife $(12.9 \%)$, as labor $(0.6 \%)$, and in other occupation (11.2\%) and half of the respondents are not working as they are physically weak due to their old age. The highest numbers of respondents (61.2\%) are living with their family and the lowest numbers of respondents (2.4\%) are living with their daughter/son-in-law. Similarly, 20.6 percent of respondents live with their spouse separately and 15.9 percent of the respondents live alone.

Most of the respondents (30.6\%) have a monthly family income of 5000 and fewer rupees which is followed by 20001 to 30000 rupees and above 30000 rupees, both of which comprise 21.8 percent of respondents each. Similarly, only 14.1 percent 
NJISS Volume $4 \quad$ Issue $1 \quad$ ISSN:2565-4942 (Print) 2738-9693 (Online)

of respondents have a family income of rupees 5001 to 10000 rupees and the lowest number of respondents (11.8\%) have a monthly family income of 10001 to 20000 rupees.

The majority of the respondents are getting an old age allowance that consists of 50.6 percent. Similarly, 24.1 percent are getting widow allowance, 19.4 percent are getting a Dalit allowance and 5.9 percent are getting a disabled allowance. Most of the respondents (60.6\%) have been receiving an allowance for 5 years and above, followed by 3 to 4 years (19.4\%), 1 to 2 years $(12.9 \%)$, and less than one year $(7.1 \%)$.

\section{Descriptive Statistics}

This section includes the mean score calculation on socio-economic well-being perceived by the beneficiaries. Different indicators are used from previous studies to measure the social-economic well-being of the beneficiaries and these indicators were finalized with the help of experts. These indicators are measured in the 5 Points Likert Scale as strongly disagree (1), disagree (2), neutral (3), agree (4), and strongly agree (5). The output of descriptive statistics is given in table 2.

\section{Table 2}

Descriptive Statistics of Socio-Economic Well-beings Perceived

\begin{tabular}{lcc}
\hline \multicolumn{1}{c}{ Statements } & Mean & SD \\
\hline I feel that my financial dependency on others has decreased due to allowance & 4.26 & 1.00 \\
The allowance helps me to meet my regular household expenditure & 4.04 & .960 \\
It helps to save money for future & 1.92 & 1.01 \\
It helps to increase health awareness & 3.77 & 1.04 \\
It helps to purchase health service and medicine & 3.94 \\
It helps to increase the frequency of visiting doctors & 3.41 \\
It helps to increase nutritious foods and safe drinking water & 3.89 \\
The allowance helps to increase the number of friends in some ways & 1.14 \\
The allowance helps to get involved in social activities. & 3.87 \\
Allowance has increased your importance on peers and associates & 3.66 & 0.94 \\
I feel honored that the government is taking care of me & 3.73 \\
I think neighbors respect me as a beneficiary of allowance & 4.53 & 0.98 \\
The allowance helps to increase my self-respect. & 3.99 & 0.93 \\
It helps to increase my food consumption & 4.28 \\
It helps to increase my health access & 3.93 \\
It helps to meet my clothing needs & 0.89 \\
\hline
\end{tabular}

( $N=170,1$ = Strongly Disagree, 3 = Neutral, and 5 = Strongly Agree)

Source: Field survey, 2020 and authors' calculation.

Table 2 presents the mean score evaluation of the scales used in assessing the social-economic well-being perceived by the beneficiaries of social security allowance. The mean scores of all the statements related to the measurement of socioeconomic well-being (except one) are more than 3 which indicates that most of the respondents are agreed on social security allowance helps to get the socio-economic well-being of the respondents. The mean score of 1.92 indicates that allowance money is not sufficient to save for future emergencies 


\section{Problems faced by respondents while getting allowance}

This section includes the proportion of recipients facing problems while getting an allowance and the type of problems faced by them.

Figure 1

Problem faced by respondents

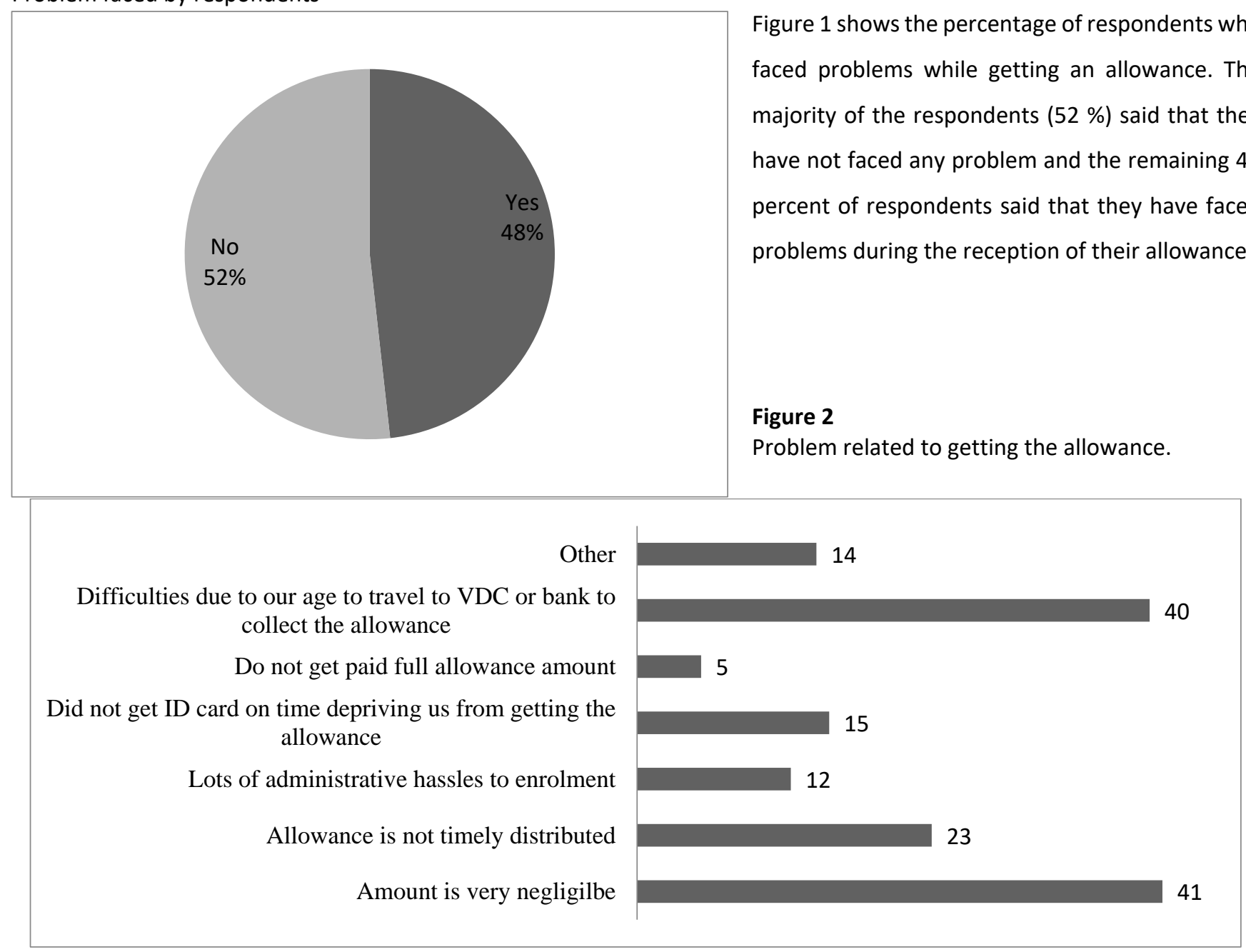

Figure 2 shows different problems faced by respondents while getting their allowance. The majority of the respondents (41 respondents) reported that the amount of allowance is very negligible followed by difficulties to travel to VDC or bank to collect the allowance which consists of 40 respondents. Likewise, other problems related to getting allowance are untimely distribution, ID card problems, a lot of administrative hassle, not getting the full amount of allowance, and others such as long queue, the problem of late receiving of allowances due to age error in the document. 
NJISS Volume $4 \quad$ Issue $1 \quad$ ISSN:2565-4942 (Print) 2738-9693 (Online)

Differences in the socio-economic status of the respondents

Various factors make differences in the socio-economic status of the respondents. Independent sample t-test and one way ANOVA were applied between socio-economic status and other demographic variables such as area, gender, marital status, ethnic group, education level, working status, living arrangement, monthly income of a family, type of allowance, duration of getting an allowance, and allowance as a major source of income to find the differences in the socio-economic status of the beneficiaries.

Table 3

Independent Sample T-test between Male and Female

\begin{tabular}{|l|l|c|c|c|}
\hline Socio-Economic Variables & Gender & $\mathbf{N}$ & Mean & P-value \\
\hline \multirow{2}{*}{ Economic Well-being } & Male & 70 & 3.4095 & 0.931 \\
\cline { 2 - 4 } & Female & 100 & 3.4000 & \\
\hline \multirow{2}{*}{ Health Access } & Male & 70 & 3.7036 & 0.432 \\
\cline { 2 - 4 } & Female & 100 & 3.6025 & \\
\hline \multirow{2}{*}{ Social Status } & Male & 70 & 3.9286 & $0.020^{*}$ \\
\cline { 2 - 4 } & Female & 100 & 3.6300 & \\
\hline \multirow{2}{*}{ Self-respect \& Respect from Others } & Male & 70 & 4.3381 & 0.330 \\
\cline { 2 - 4 } & Female & 100 & 4.2200 & \\
\hline \multirow{2}{*}{ Living Standard } & Male & 70 & 3.6619 & 0.711 \\
\cline { 2 - 4 } & Female & 100 & 3.6133 & \\
\hline
\end{tabular}

** Significant at the $1 \%$ level of significance, * significant at the $5 \%$ level of significance

Source: Field survey, 2020 and authors' calculation.

Table 3 shows the results of independent sample t-test by gender. There is a significant difference in social status between male recipients and female recipients $(P<0.05)$. However, there is no significant difference in economic well-being, health access, respect, and living standard between male recipients and female recipients $(P>0.05)$.

Table 4

Independent Sample T-test by Area

\begin{tabular}{|c|c|c|c|c|}
\hline Socio-Economic Variables & Area & $\mathbf{N}$ & Mean & P-value \\
\hline \multirow[t]{2}{*}{ Economic Well-being } & Pokhara Metropolitan & 85 & 3.5098 & \multirow[t]{2}{*}{$0.048^{*}$} \\
\hline & Rupa Rural Municipality & 85 & 3.2980 & \\
\hline \multirow[t]{2}{*}{ Health Access } & Pokhara Metropolitan & 85 & 3.8971 & \multirow[t]{2}{*}{$0.000 * *$} \\
\hline & Rupa Rural Municipality & 85 & 3.3912 & \\
\hline \multirow[t]{2}{*}{ Social Status } & Pokhara Metropolitan & 85 & 3.8745 & \multirow[t]{2}{*}{0.056} \\
\hline & Rupa Rural Municipality & 85 & 3.6314 & \\
\hline \multirow[t]{2}{*}{ Self-respect \& Respect from Others } & Pokhara Metropolitan & 85 & 4.2941 & \multirow[t]{2}{*}{0.670} \\
\hline & Rupa Rural Municipality & 85 & 4.2431 & \\
\hline \multirow[t]{2}{*}{ Living Standard } & Pokhara Metropolitan & 85 & 3.8235 & \multirow[t]{2}{*}{$0.003^{* *}$} \\
\hline & Rupa Rural Municipality & 85 & 3.4431 & \\
\hline
\end{tabular}

** Significant at the $1 \%$ level of significance, * significant at the $5 \%$ level of significance

Source: Field survey, 2020 and authors' calculation. 
Table 4 shows the socio-economic differences between the respondents of two different areas. There is a significant difference in economic well-being, health access, and living standard between the recipients of Pokhara Metropolitan and Rupa Rural Municipality $(\mathrm{P}<0.05)$. However, there is no significant difference in social status and respect between the recipients of two different areas $(P>0.05)$.

Table 5

Independent Sample T-test by Allowance as Major Source of Income

\begin{tabular}{|l|l|c|c|c|}
\hline \multirow{2}{*}{ Socio-Economic Variables } & $\begin{array}{l}\text { Allowance as a Major } \\
\text { Source of Income }\end{array}$ & N & Mean & P-value \\
\hline Economic Well-being & Yes & 127 & 3.5197 & $0.000^{* *}$ \\
\cline { 2 - 4 } & No & 43 & 3.0620 & \\
\hline \multirow{2}{*}{ Health Access } & Yes & 127 & 3.6988 & 0.137 \\
\cline { 2 - 4 } & No & 43 & 3.4826 & \\
\hline \multirow{2}{*}{ Social Status } & Yes & 127 & 3.7375 & 0.678 \\
\cline { 2 - 4 } & No & 43 & 3.7984 & \\
\hline Self-respect \& Respect from Others & Yes & 127 & 4.3360 & $0.050^{*}$ \\
\cline { 2 - 4 } & No & 43 & 4.0698 & \\
\hline Living Standard & Yes & 127 & 3.7060 & $0.050^{*}$ \\
\cline { 2 - 4 } & No & 43 & 3.4186 & \\
\hline
\end{tabular}

** Significant at the $1 \%$ level of significance, * significant at the $5 \%$ level of significance Source: Field survey, 2020 and authors' calculation.

Table 5 shows the socio-economic differences between the respondents by allowance as a major source of income. There is a significant difference in economic well-being, respect, and living standard between the recipients whose major income source is allowance and those who have another major source of income $(\mathrm{P}<=0.05)$. However, there is no significant difference in health status and social status between the recipients by allowance as a major source of income $(P>0.05)$.

\section{Table 6}

One Way ANOVA by Marital Status

\begin{tabular}{|c|c|c|c|c|c|c|}
\hline Socio-Economic Variables & Source of Variance & Sum of Squares & df & Mean Square & $\mathbf{F}$ & Sig. \\
\hline \multirow[t]{3}{*}{ Economic Well-being } & Between Groups & 0.248 & 3 & .083 & \multirow[t]{3}{*}{.167} & \multirow[t]{3}{*}{.919} \\
\hline & Within Groups & 82.460 & 166 & .497 & & \\
\hline & Total & 82.708 & 169 & & & \\
\hline \multirow[t]{3}{*}{ Health Access } & Between Groups & 3.107 & 3 & 1.036 & \multirow[t]{3}{*}{1.544} & \multirow[t]{3}{*}{.205} \\
\hline & Within Groups & 111.363 & 166 & .671 & & \\
\hline & Total & 114.469 & 169 & & & \\
\hline \multirow[t]{3}{*}{ Social Status } & Between Groups & 3.552 & 3 & 1.184 & \multirow[t]{3}{*}{1.747} & \multirow[t]{3}{*}{.159} \\
\hline & Within Groups & 112.516 & 166 & .678 & & \\
\hline & Total & 116.068 & 169 & & & \\
\hline \multirow{3}{*}{$\begin{array}{l}\text { Self-Respect } \quad \& \quad \text { Respect } \\
\text { from Others }\end{array}$} & Between Groups & 0.809 & 3 & .270 & \multirow[t]{3}{*}{.444} & \multirow[t]{3}{*}{.722} \\
\hline & Within Groups & 100.813 & 166 & .607 & & \\
\hline & Total & 101.622 & 169 & & & \\
\hline \multirow[t]{3}{*}{ Living Standard } & Between Groups & 3.906 & 3 & 1.302 & \multirow[t]{3}{*}{1.888} & \multirow[t]{3}{*}{.133} \\
\hline & Within Groups & 114.460 & 166 & .690 & & \\
\hline & Total & 118.367 & 169 & & & \\
\hline
\end{tabular}

** Significant at the $1 \%$ level of significance, * significant at the $5 \%$ level of significance Source: Field survey, 2020 and authors' calculation. 
Table 6 shows the results of one-way ANOVA by marital status. It is found that there is no significant difference in socioeconomic variables among the recipients by the marital status $(P>0.05)$.

Table 7

One Way ANOVA by Education Level

\begin{tabular}{|c|c|c|c|c|c|c|}
\hline Socio-Economic Variables & Source of Variance & Sum of Squares & df & Mean Square & $\mathbf{F}$ & Sig. \\
\hline \multirow[t]{3}{*}{ Economic Well-being } & Between Groups & 0.496 & 3 & .165 & \multirow[t]{3}{*}{.334} & \multirow[t]{3}{*}{.801} \\
\hline & Within Groups & 82.213 & 166 & .495 & & \\
\hline & Total & 82.708 & 169 & & & \\
\hline \multirow[t]{3}{*}{ Health Access } & Between Groups & 0.831 & 3 & 0.277 & \multirow[t]{3}{*}{.404} & \multirow[t]{3}{*}{.750} \\
\hline & Within Groups & 113.639 & 166 & .685 & & \\
\hline & Total & 114.469 & 169 & & & \\
\hline \multirow[t]{3}{*}{ Social Status } & Between Groups & 5.577 & 3 & 1.859 & \multirow[t]{3}{*}{2.793} & \multirow[t]{3}{*}{$.042^{*}$} \\
\hline & Within Groups & 110.491 & 166 & .666 & & \\
\hline & Total & 116.068 & 169 & & & \\
\hline \multirow{3}{*}{$\begin{array}{l}\text { Self-Respect \& Respect } \\
\text { from Others }\end{array}$} & Between Groups & 0.772 & 3 & .257 & \multirow[t]{3}{*}{.424} & \multirow[t]{3}{*}{.736} \\
\hline & Within Groups & 100.849 & 166 & .608 & & \\
\hline & Total & 101.622 & 169 & & & \\
\hline \multirow[t]{3}{*}{ Living Standard } & Between Groups & 1.632 & 3 & 0.544 & \multirow[t]{3}{*}{.774} & \multirow[t]{3}{*}{.510} \\
\hline & Within Groups & 116.734 & 166 & .703 & & \\
\hline & Total & 118.367 & 169 & & & \\
\hline
\end{tabular}

** Significant at the $1 \%$ level of significance, * significant at the $5 \%$ level of significance

Source: Field survey, 2020 and authors' calculation.

The results of one-way ANOVA by education level are presented in table 7. There is a significant difference in social status among the recipients of different education levels $(P<0.05)$. However, there is no significant difference in economic wellbeing, health access, respect, and living standard among the recipients by education level $(P>0.05)$.

Table 8

One Way ANOVA by Ethnic Group

\begin{tabular}{|c|c|c|c|c|c|c|}
\hline Socio-Economic Variables & Source of Variance & Sum of Squares & df & Mean Square & $\mathbf{F}$ & Sig. \\
\hline \multirow[t]{3}{*}{ Economic Well-being } & Between Groups & 3.428 & 3 & 1.143 & \multirow[t]{3}{*}{2.392} & \multirow[t]{3}{*}{.070} \\
\hline & Within Groups & 79.281 & 166 & .478 & & \\
\hline & Total & 82.708 & 169 & & & \\
\hline \multirow[t]{3}{*}{ Health Access } & Between Groups & 2.066 & 3 & 0.689 & \multirow[t]{3}{*}{1.017} & \multirow[t]{3}{*}{.387} \\
\hline & Within Groups & 112.403 & 166 & .677 & & \\
\hline & Total & 114.469 & 169 & & & \\
\hline \multirow[t]{3}{*}{ Social Status } & Between Groups & 2.762 & 3 & 0.921 & \multirow[t]{3}{*}{1.349} & \multirow[t]{3}{*}{.260} \\
\hline & Within Groups & 113.306 & 166 & .683 & & \\
\hline & Total & 116.068 & 169 & & & \\
\hline \multirow{3}{*}{$\begin{array}{l}\text { Self-Respect \& Respect } \\
\text { from Others }\end{array}$} & Between Groups & 3.769 & 3 & 1.256 & \multirow[t]{3}{*}{2.131} & \multirow[t]{3}{*}{.098} \\
\hline & Within Groups & 97.853 & 166 & .589 & & \\
\hline & Total & 101.622 & 169 & & & \\
\hline \multirow[t]{3}{*}{ Living Standard } & Between Groups & 3.043 & 3 & 1.014 & \multirow[t]{3}{*}{1.460} & \multirow[t]{3}{*}{.227} \\
\hline & Within Groups & 115.323 & 166 & .695 & & \\
\hline & Total & 118.367 & 169 & & & \\
\hline
\end{tabular}

** Significant at the $1 \%$ level of significance, * significant at the $5 \%$ level of significance Source: Field survey, 2020 and authors' calculation. 
Table 8 shows the results of one-way ANOVA by different ethnic groups. It is found that there is no significant difference in the socio-economic impact of allowance among the recipients of different ethnic groups $(P>0.05)$.

Table 9

One Way ANOVA by Employment Status

\begin{tabular}{|c|c|c|c|c|c|c|}
\hline Socio-Economic Variables & Source of Variance & Sum of Squares & df & Mean Square & $\mathbf{F}$ & Sig. \\
\hline \multirow[t]{3}{*}{ Economic Well-being } & Between Groups & 5.085 & 4 & 1.271 & \multirow[t]{3}{*}{2.702} & \multirow[t]{3}{*}{$.032 *$} \\
\hline & Within Groups & 77.624 & 165 & .470 & & \\
\hline & Total & 82.708 & 169 & & & \\
\hline \multirow[t]{3}{*}{ Health Access } & Between Groups & 7.156 & 4 & 1.789 & \multirow[t]{3}{*}{2.751} & \multirow[t]{3}{*}{$.030^{*}$} \\
\hline & Within Groups & 107.313 & 165 & .650 & & \\
\hline & Total & 114.469 & 169 & & & \\
\hline \multirow[t]{3}{*}{ Social Status } & Between Groups & 3.806 & 4 & 0.951 & \multirow[t]{3}{*}{1.398} & \multirow[t]{3}{*}{.237} \\
\hline & Within Groups & 112.262 & 165 & .680 & & \\
\hline & Total & 116.068 & 169 & & & \\
\hline \multirow{3}{*}{$\begin{array}{l}\text { Self-Respect \& Respect } \\
\text { from Others }\end{array}$} & Between Groups & 2.662 & 4 & .666 & \multirow[t]{3}{*}{1.110} & \multirow[t]{3}{*}{.354} \\
\hline & Within Groups & 98.959 & 165 & .600 & & \\
\hline & Total & 101.622 & 169 & & & \\
\hline \multirow[t]{3}{*}{ Living Standard } & Between Groups & 5.339 & 4 & 1.335 & \multirow[t]{3}{*}{1.948} & \multirow[t]{3}{*}{.105} \\
\hline & Within Groups & 113.028 & 165 & .685 & & \\
\hline & Total & 118.367 & 169 & & & \\
\hline
\end{tabular}

** Significant at the $1 \%$ level of significance, * significant at the $5 \%$ level of significance Source: Field survey, 2020 and authors' calculation.

Table 9 shows the results of one-way ANOVA by employment status. There is a significant difference in economic well-being and health access among the recipients of different employment statuses $(P<0.05)$. However, there is no significant difference in social status, respect, and living standard among the recipients of different employment statuses $(P>0.05)$.

\section{Table 10}

One Way ANOVA by Living Arrangement

\begin{tabular}{|c|c|c|c|c|c|c|}
\hline Socio-Economic Variables & Source of Variance & Sum of Squares & df & Mean Square & $\mathbf{F}$ & Sig. \\
\hline \multirow[t]{3}{*}{ Economic Well-being } & Between Groups & 2.337 & 3 & .779 & \multirow[t]{3}{*}{1.609} & \multirow[t]{3}{*}{.189} \\
\hline & Within Groups & 80.371 & 166 & .484 & & \\
\hline & Total & 82.708 & 169 & & & \\
\hline \multirow[t]{3}{*}{ Health Access } & Between Groups & 1.471 & 3 & 0.490 & \multirow[t]{3}{*}{.720} & \multirow[t]{3}{*}{.541} \\
\hline & Within Groups & 112.998 & 166 & .681 & & \\
\hline & Total & 114.469 & 169 & & & \\
\hline \multirow[t]{3}{*}{ Social Status } & Between Groups & 3.938 & 3 & 1.313 & \multirow[t]{3}{*}{1.943} & \multirow[t]{3}{*}{.125} \\
\hline & Within Groups & 112.130 & 166 & .675 & & \\
\hline & Total & 116.068 & 169 & & & \\
\hline \multirow{3}{*}{$\begin{array}{l}\text { Self-Respect \& Respect } \\
\text { from Others }\end{array}$} & Between Groups & 2.902 & 3 & .967 & \multirow[t]{3}{*}{1.627} & \multirow[t]{3}{*}{.185} \\
\hline & Within Groups & 98.719 & 166 & .595 & & \\
\hline & Total & 101.622 & 169 & & & \\
\hline \multirow[t]{3}{*}{ Living Standard } & Between Groups & 6.385 & 3 & 2.128 & \multirow[t]{3}{*}{3.155} & \multirow[t]{3}{*}{$.026^{*}$} \\
\hline & Within Groups & 111.982 & 166 & .675 & & \\
\hline & Total & 118.367 & 169 & & & \\
\hline
\end{tabular}

** Significant at the $1 \%$ level of significance, * significant at the $5 \%$ level of significance Source: Field survey, 2020 and authors' calculation. 
Table 10 shows the results of one-way ANOVA by living arrangement. There is a significant difference in the living standards of the recipients by different living arrangements $(P<0.05)$. However, there is no significant difference in economic well-being, health access, social status, and respect among the recipients of different living arrangements $(P>0.05)$.

Table 11

One Way ANOVA by Monthly Family Income

\begin{tabular}{|c|c|c|c|c|c|c|}
\hline Socio-Economic Variables & Source of Variance & Sum of Squares & df & Mean Square & $\mathbf{F}$ & Sig. \\
\hline \multirow[t]{3}{*}{ Economic Well-being } & Between Groups & 2.529 & 4 & .632 & \multirow[t]{3}{*}{1.301} & \multirow[t]{3}{*}{.272} \\
\hline & Within Groups & 80.180 & 165 & .486 & & \\
\hline & Total & 82.708 & 169 & & & \\
\hline \multirow[t]{3}{*}{ Health Access } & Between Groups & 4.362 & 4 & 1.091 & \multirow[t]{3}{*}{1.634} & \multirow[t]{3}{*}{.168} \\
\hline & Within Groups & 110.107 & 165 & .667 & & \\
\hline & Total & 114.469 & 169 & & & \\
\hline \multirow[t]{3}{*}{ Social Status } & Between Groups & 1.178 & 4 & 0.294 & \multirow[t]{3}{*}{.423} & \multirow[t]{3}{*}{.792} \\
\hline & Within Groups & 114.890 & 165 & .696 & & \\
\hline & Total & 116.068 & 169 & & & \\
\hline \multirow{3}{*}{$\begin{array}{l}\text { Self-Respect \& Respect } \\
\text { from Others }\end{array}$} & Between Groups & 2.381 & 4 & .595 & \multirow[t]{3}{*}{.990} & \multirow[t]{3}{*}{.415} \\
\hline & Within Groups & 99.240 & 165 & .601 & & \\
\hline & Total & 101.622 & 169 & & & \\
\hline \multirow[t]{3}{*}{ Living Standard } & Between Groups & 2.481 & 4 & 0.620 & \multirow[t]{3}{*}{.883} & \multirow[t]{3}{*}{.475} \\
\hline & Within Groups & 115.886 & 165 & .702 & & \\
\hline & Total & 118.367 & 169 & & & \\
\hline
\end{tabular}

** Significant at the $1 \%$ level of significance, * significant at the $5 \%$ level of significance Source: Field survey, 2020 and authors' calculation.

Table 11 presents the results of one-way ANOVA by the monthly income of the family. It is found that there is no significant difference in socio-economic status among the recipients having a different monthly family income $(P>0.05)$.

\section{Table 12}

One Way ANOVA by Type of Allowance

\begin{tabular}{|c|c|c|c|c|c|c|}
\hline Socio-Economic Variables & Source of Variance & Sum of Squares & df & Mean Square & $\mathbf{F}$ & Sig. \\
\hline \multirow[t]{3}{*}{ Economic Well-being } & Between Groups & .711 & 3 & .237 & \multirow[t]{3}{*}{.479} & \multirow[t]{3}{*}{.697} \\
\hline & Within Groups & 81.998 & 166 & .494 & & \\
\hline & Total & 82.708 & 169 & & & \\
\hline \multirow[t]{3}{*}{ Health Access } & Between Groups & 4.051 & 3 & 1.350 & \multirow[t]{3}{*}{2.030} & \multirow[t]{3}{*}{.112} \\
\hline & Within Groups & 110.418 & 166 & .665 & & \\
\hline & Total & 114.469 & 169 & & & \\
\hline \multirow[t]{3}{*}{ Social Status } & Between Groups & 1.296 & 3 & 0.432 & \multirow[t]{3}{*}{.625} & \multirow[t]{3}{*}{.600} \\
\hline & Within Groups & 114.772 & 166 & .691 & & \\
\hline & Total & 116.068 & 169 & & & \\
\hline \multirow{3}{*}{$\begin{array}{l}\text { Self-Respect \& Respect } \\
\text { from Others }\end{array}$} & Between Groups & .495 & 3 & .165 & \multirow[t]{3}{*}{.271} & \multirow[t]{3}{*}{.846} \\
\hline & Within Groups & 101.127 & 166 & .609 & & \\
\hline & Total & 101.622 & 169 & & & \\
\hline \multirow[t]{3}{*}{ Living Standard } & Between Groups & 1.867 & 3 & 0.622 & \multirow[t]{3}{*}{.887} & \multirow[t]{3}{*}{.449} \\
\hline & Within Groups & 116.500 & 166 & .702 & & \\
\hline & Total & 118.367 & 169 & & & \\
\hline
\end{tabular}

\footnotetext{
** Significant at the $1 \%$ level of significance, * significant at the $5 \%$ level of significance
} Source: Field survey, 2020 and authors' calculation. 
Table 12 presents the results of one-way ANOVA by type of allowance. It is found that there is no significant difference in socio-economic impact of allowance among the recipients getting different types of allowance $(P>0.05)$.

Table 13

One Way ANOVA by Years of Receiving Allowance

\begin{tabular}{|c|c|c|c|c|c|c|}
\hline Socio-Economic Variables & Source of Variance & Sum of Squares & Df & Mean Square & $\mathbf{F}$ & Sig. \\
\hline \multirow[t]{3}{*}{ Economic Well-being } & Between Groups & 14.391 & 3 & 4.797 & \multirow[t]{3}{*}{11.655} & \multirow[t]{3}{*}{$.000 * *$} \\
\hline & Within Groups & 68.318 & 166 & .412 & & \\
\hline & Total & 82.708 & 169 & & & \\
\hline \multirow[t]{3}{*}{ Health Access } & Between Groups & 32.811 & 3 & 10.937 & \multirow[t]{3}{*}{22.234} & \multirow[t]{3}{*}{$.000^{* *}$} \\
\hline & Within Groups & 81.658 & 166 & .492 & & \\
\hline & Total & 114.469 & 169 & & & \\
\hline \multirow[t]{3}{*}{ Social Status } & Between Groups & 4.525 & 3 & 1.508 & \multirow[t]{3}{*}{2.245} & \multirow[t]{3}{*}{.085} \\
\hline & Within Groups & 111.543 & 166 & .672 & & \\
\hline & Total & 116.068 & 169 & & & \\
\hline \multirow{3}{*}{$\begin{array}{l}\text { Self-Respect \& Respect } \\
\text { from Others }\end{array}$} & Between Groups & 12.283 & 3 & 4.094 & \multirow[t]{3}{*}{7.608} & \multirow[t]{3}{*}{$.000 * *$} \\
\hline & Within Groups & 89.339 & 166 & .538 & & \\
\hline & Total & 101.622 & 169 & & & \\
\hline \multirow[t]{3}{*}{ Living Standard } & Between Groups & 19.664 & 3 & 6.555 & \multirow[t]{3}{*}{11.024} & \multirow[t]{3}{*}{$.000 * *$} \\
\hline & Within Groups & 98.703 & 166 & .595 & & \\
\hline & Total & 118.367 & 169 & & & \\
\hline
\end{tabular}

** Significant at the $1 \%$ level of significance, * significant at the $5 \%$ level of significance

Source: Field survey, 2020 and authors' calculation.

Table 13 shows the results of one-way ANOVA by the years of receiving an allowance. There is a significant difference in economic well-being, health access, respect, and living standard of the recipients by the duration of receiving an allowance $(P<0.05)$. However, there are no significant differences in the social status of the recipients by the duration of receiving an allowance $(\mathrm{P}>0.05)$.

\section{Conclusion}

Social security allowance helps to increase economic well-being, health status, social status, self-respect and respect from others, and living standard of the beneficiaries in different aspects. Social security benefits play a very important role in improving the socio-economic status of the beneficiaries in different aspects.

Around half of the beneficiaries are facing some kinds of problems while getting an allowance. Difficulties to travel to Rural Municipality or bank to collect allowance and less amount of allowance are the major problems related to allowance in Nepal. Similarly, area, employment status, duration of getting an allowance, and allowance as a major source of income are the major factors that make differences in the socio-economic status of recipients. From this study, the researchers suggest to the policymakers that the amount of allowance needs to be increased at least to meet the basic requirements of the elderly and allowance should be provided on the basis of current income of the recipients.

\section{Acknowledgement}


NJISS Volume $4 \quad$ Issue 1 ISSN:2565-4942 (Print) 2738-9693 (Online)

We would like to thank the staffs of Pokhara Metropolitan and Rupa Rural Municipality office for providing the details of social security allowance recipients on the concerned wards. Thanks to Pokhara University Research Center (PURC) for providing grant for this study and to the respondents for providing valuable inputs for our study.

Funding Information

This research is partially funded by Pokhara University Research Center (PURC).

Author contributions

Conceptualization: Ranabhat D. \& Adhikari Methodology: Ranabhat D. \& Adhikari; Literature Review: All authors

Software: Ranabhat D., Formal Analysis: Ranabhat D.; Data Collection: All authors, Writing - Original Draft: Ranabhat D., Adhikari \& Sapkota, Writing - Review \& Editing: Ranabhat D., Adhikari \& Sapkota,

Disclosure statement / Conflict of interest

The authors declare no conflict of interest.

Ethical statement

This research did not require an ethical approval as it does not involve any human or animal experiment.

Data deposition

Data have been used only for this paper.

Author ORCID information

Deepesh Ranabhat

https://orcid.org/0000-0003-0503-1335 
NJISS Volume $4 \quad$ Issue 1 ISSN:2565-4942 (Print) 2738-9693 (Online)

\section{References}

Choudhary, R. (2013). Impact of old age allowance among rural aged: An empirical investigation. International Journal of Sociology and Anthropology, 5(7), 262-268. https://doi.org/10.5897/ijsa2013.0453

Dhungana A. R. \& Ranabhat M. (2018). Factors Associated with Socio-Economic Status of Dalit People Getting Old Age Allowance in Pokhara. ICMA-MU 2018 Book on the Conference Proceedings 2018: 61-68. Bangkok, Thailand.

Dhungana, G. P., Sapkota, M., \& Bista, B. (2020). Older people's satisfaction with and utilisation patterns of the Old Age Allowance in Nepal. Australasian Journal on Ageing, 39(2), e178-e184. https://doi.org/10.1111/ajag.12729

George, D., \& Mallery, P. (2003). SPSS for Windows step by step: A simple guide and reference. 11.0 update (4th ed.). Boston: Allyn \& Bacon

Hasan, M. M. (2012). Effectiveness of Old Age Allowance Program in Bangladesh: A Study on the Demand Side Dynamics. North South University, Bangladesh.

Khan, N. J. (2012). An Assessment of Widow Allowance Programme in Bangladesh - the Supply Side Perspectives. Master Thesis Submitted to North South University, Bangladesh. Available at http://www.northsouth.edu/newassets/files/ppg-research/ppg-1st-3rd-batch/396_Nilufar.pdf

Li, Q., Wang, Y., \& Zhao, Y. (2018). The Impact of China's New Rural Pension Program on Elderly Labor, Grandchild Care, and Old-Age Support. Feminist Economics, 24(2), 265-287. https://doi.org/10.1080/13545701.2017.1421768

Malakar, I., \& Chalise, H. N. (2019). Perception of Elderly towards Social Security Allowance in Nepal. South Asian Journal of Social Studies and Economics, January 2019, 1-9. https://doi.org/10.9734/sajsse/2018/v2i430008

Mugomeri, E., Chatanga, P., Khetheng, T., \& Dhemba, J. (2017). Quality of Life of the Elderly Receiving Old Age Pension in Lesotho. Journal of Aging and Social Policy, 29(4), 371-393. https://doi.org/10.1080/08959420.2017.1328952

National Planning Commission. (2012). Assessment of Social Security Allowance Program in Nepal (Issue May).

Riumallo-Herl, C., \& Aguila, E. (2019). The effect of old-age pensions on health care utilization patterns and insurance uptake in Mexico. BMJ Global Health, 4(6), 1-10. https://doi.org/10.1136/bmjgh-2019-001771

Salinas-Rodríguez, A., Torres-Pereda, M. D. P., Manrique-Espinoza, B., Moreno-Tamayo, K., \& Solís, M. M. T. R. (2014). Impact of the non-contributory social pension program 70 y más on older adults' mental well-being. PLOS ONE, 9(11), 1-10. https://doi.org/10.1371/journal.pone.0113085

Unnikrishnan, V., \& Imai, K. S. (2020). Does the old-age pension scheme improve household welfare? Evidence from India. World Development, 134(2020). https://doi.org/10.1016/j.worlddev.2020.105017 